\title{
THE EFFECT OF HYPERCHOLESTEROL HERBS FORMULA ON THE QUALITY OF LIFE
}

\author{
Agus Triyono'), Setyo Sri Rahardjo²), Fajar Novianto3) \\ 1)Masters Program in Public Health, Universitas Sebelas Maret \\ 2)Faculty of Medicine, Universitas Sebelas Maret \\ 3) Research and Development Center of Medicinal Plants and Traditional Medicines
}

\begin{abstract}
Background: Hypercholesterolemia is a metabolic disorder that is often found in the community. Hypercholesterolemia is a chronic disease, which requires a long treatment, even for long life. This study aimed to determine the effectiveness of hypercholesterol herbs formula, in improving quality of life.

Subjects and Method: A quasi experimental study before and after with no control design was conducted at the Jamu Research House, Tawangmangu, Central Java. A sample of 78 hypercholesterolemia patients received hypercholesterol herbs formula for 42 days. The dependent variable was quality of life. The independent variable was hypercholesterol herbs administration. Quality of life was measured by short form-36 (SF-36) questionnaire. The data were analyzed by paired t-test.

Results: The score of quality of life of subjects after treatment (mean = 80.72; SD =12.16) was higher than before (mean=73.44; $\mathrm{SD}=14.71)$ and it was statistically significant $(\mathrm{p}<0.001)$.

Conclusion: Hypercholesterol herbs formula is effective to improve the quality of life of patients with hypercholesterolemia.
\end{abstract}

Keywords: Hypercholesterolemia, herbs formula, quality of life

\section{Correspondence:}

Agus Triyono. Masters Program in Public Health, Universitas Sebelas Maret, Jl. Ir. Sutami 36A, Surakarta 57126, Central Java. Email: agustriyono_21@yahoo.com. Mobile: 081329038465.

\section{BACKGROUND}

Hypercholesterolemia is part of metabolic syndrome, and is a risk factor for atherosclerosis. Atherosclerosis is the most common cause of death and is a health problem in the world. The results of epidemiological studies show that an increase in blood cholesterol levels increases the risk of coronary heart disease (CHD) and atherosclerosis (Tjokroprawiro, 2015)

CHD is the eighth leading cause of death in Indonesia and the first cause of death in the world (MOH, 2007). Based on data from Basic Health Research (Riskesdas) in 2013 the proportion of Indonesia's population with more than normal total cholesterol levels was more in women (39.6\%) than in men (30.0\%) (Ministry of Health, 2013)

Hypercholesterolemia is a degenerative disease that requires life-long treatment. This condition often makes patients bored with conventional treatment and chooses treatment with herbs. Some herbal formulas that are hereditary are used to reduce blood cholesterol levels (Horrison, 2001).

The herbal formula consisting of Cassia sennae L leaf, Guazuma ulmifolia L leaf, Sonchus arvensis leaf and Camillia sinensis $L$ leaf is one of the blood cholesterol-lowering herbal formulas that has the potential to be studied. Quality of life is one of the factors associated with patient morbidity and mor- 
tality. Quality of life is a multidimensional concept that includes physical, social and psychological dimensions related to illness and therapy (Testa and Simondson, 1996; Gotay et al., 1992). Short Form-36 (SF-36) is one example of quality of life instruments that have been widely used in various countries for various chronic diseases and have been developed by many researchers (Ware, 2005)

SF-36 can provide a more complete picture by describing 8 aspects namely a) restrictions on physical activity due to existing health problems, b) restrictions on social activities due to physical and emotional problems, c) restrictions on daily activities due to physical problems, d) overall pain body, e) general mental health, f) restrictions on daily activities due to emotional problems, g) vitality of life, and $\mathrm{h}$ ) general health outlook. Using SF36 is fast (5-10 minutes) and easy to do. (WHO, 1997).

An observational studies have been conducted on the effect of the use of the blood cholesterol formula for the quality of life of hypercholesterolemia patients. This study can support the evidence base formula for lowering blood cholesterol so that it can be used in the community.

\section{SUBJECTS AND METHOD}

\section{Study Design}

The clinical trial was carried out with a quasiexperimental study design pre and post design. The study was conducted at the Research House for Herbal Medicine B2P2TO2T Tawangmangu.

\section{Population and Sample}

Subjects were 78 people who had hypercholesterolemia and were treated at the Herbal Medicine Research House B2P2TO2T Tawangmangu.
Inclusion criteria: prospective subjects aged 25-55 years, blood cholesterol levels $200-300 \mathrm{mg} / \mathrm{dl}$, willing to follow the course of the study/follow-up schedule by signing informed consent. Exclusion criteria: prospective subjects taking blood cholesterollowering drugs, pregnant, subjects with severe disease complications such as heart problems and cancer.

Subjects who had signed informed consent, on the day before the intervention (Ho) were carried out anamnesis identity, history of disease, clinical symptoms, diagnostic physical examination, and assessment of quality of life scores with SF- 36 as baseline data. The SF-36 score assessment was carried out by independent nurses who had attended the SF-36 assessment training before.

\section{Study Variables}

The independent variables in this study were the formula of Cassia sennae L leaf, Guazuma ulmifolia $L$ leaf, Sonchus arvensis leaf and Camillia sinensis $L$. leaf. The dependent variable in this study was quality of life.

\section{Operational Definition of the Study Variables}

Decoction of cholesterol-lowering formula boiled with one liter of water. The cooking water of the hypercholesterolemia herbal medicine formula was taken $3 \times 200 \mathrm{ml}$ every day for 42 days.

Starting the first day until the 42nd day, subjects were given a simplicia preparation of hypercholesterolemia herbal formula that had been packaged and provided with the rules of boiling herbal medicine (one package boiled with one liter of water.

\section{Study Instrument}

The measurement of quality of life used SF-36 questionnaires 


\section{Data Analysis}

Results Assessing SF-36 scores were analyzed by paired $t$ test. Ethics Commission of the Indonesian Ministry of Health's Health Research and Development Agency in Jakarta.

\section{RESULTS}

\section{Characteristics of Subjects of the Study}

The characteristics of 78 study subjects who had fulfilled the inclusion and exclusion criteria, and had followed 42 days of research can be shown in Table 1.

The subjects of the study totaled 78 people; the largest group was the age group 46$55(65.4 \%)$, female (58\%) and the work of laborers/farmers/fishermen (38.5\%). The most hypercholesterolemia subjects were in the age group 46 to 55 years. The results of the paired ttest analysis of quality of life scores between pre and post intervention are shown in Table 2.

Table-1 Demographic Characteristics of Subjects

\begin{tabular}{llcc}
\hline & Variables & n & \% \\
\hline Age & 26 to 35 years & 8 & $9.0 \%$ \\
& 36 to 45 years & 20 & $25.6 \%$ \\
Gender & 46 to 55 years & 51 & $65.4 \%$ \\
& Male & 32 & $42 \%$ \\
Occupation & Female & 46 & $58 \%$ \\
& School & 3 & $3.8 \%$ \\
& Army/Police/Civil Servants & 3 & $3.8 \%$ \\
& Peg private & 5 & $6.4 \%$ \\
& Entrepreneur & 12 & $15.5 \%$ \\
& Laborers/farmers /fishermen & 30 & $38.5 \%$ \\
\hline
\end{tabular}

Table 2 shows an increase in the quality of life scores of study subjects, namely in the preintervention 73.44 rose to 80.72 in the postintervention. There was a $9.9 \%$ increase in postintervention assessment compared to pre- intervention. Statistical analysis using paired ttest results obtained $\mathrm{p}$ value $<0.001$ so that statistically significantly different between SF36 post-intervention scores compared to preintervention.

Table 2. Results of Analysis of Paired t Tests

\begin{tabular}{cccccc}
\hline \multirow{2}{*}{ Variable } & \multicolumn{2}{c}{ Pre Intervention } & \multicolumn{2}{c}{ Post Intervention } & \multirow{2}{*}{ p } \\
\cline { 2 - 5 } & Mean & SD & Mean & SD & \\
\hline SF-36 & 73.44 & 14.71 & 80.72 & 12.16 & $<0.001$ \\
\hline
\end{tabular}

Table 3. Results of the Paired t-Test Analysis for Each SF-36 Dimension at Pre and Post Intervention.

\begin{tabular}{lccccc}
\hline \multirow{2}{*}{ Variables } & \multicolumn{2}{c}{ Pre Intervention } & \multicolumn{2}{c}{ Post Intervention } & \multirow{2}{*}{ P } \\
\cline { 2 - 5 } & Mean & SD & Mean & SD & \\
\hline Physical function & 85.21 & 16.76 & 93.66 & 12.31 & 0.028 \\
Role of Physical & 86.63 & 24.77 & 92.46 & 10.71 & 0.240 \\
Role of emotion & 91.21 & 22.52 & 96.20 & 11.17 & 0.167 \\
Vitality & 72.74 & 17.53 & 83.28 & 16.75 & 0.012 \\
Mental health & 77.67 & 15.31 & 77.82 & 15.22 & 0.943 \\
\hline
\end{tabular}




\begin{tabular}{lccccc}
\hline Social Function & 77.98 & 21.35 & 81.18 & 16.95 & 0.670 \\
Pain & 56.98 & 9.92 & 69.61 & 8.33 & 0.000 \\
General Health Function & 71.12 & 24.36 & 77.97 & 23.77 & 0.011 \\
\hline
\end{tabular}

The pain dimension was the dimension that had the lowest score $\left(\mathrm{Ho}=56.98\right.$ and $\mathrm{H}_{42}=$ 68.61). This was because complaints of hypercholesterolemia sufferers most often found were pain in the shoulders, feeling tightness at the nape of the neck, body discomfort. The results of paired t-test analysis between pre-intervention and post-intervention showed a significant difference in physical function dimensions $(\mathrm{p}=0.028)$ pain dimensions $(\mathrm{p}<0.001)$, vitality dimensions $(\mathrm{p}=$ 0.012 ) and general health dimensions ( $\mathrm{p}=$ o.011). The hypercholesterolemia herbal formula has been shown to improve physical function, reduce pain, and improve vitality and general health. While the results of paired t-test analysis between pre-intervention and postintervention were not significantly different in the dimensions of physical roles $(\mathrm{p}=0.240)$, emotional roles $(\mathrm{p}=0.167)$, mental health $(\mathrm{p}=$ $0.943)$, and social functions $(\mathrm{p}=0.670)$. The hypercholesterolemia herbal formula slightly increases the scores of these four dimensions. An illustration of the increase in scores for each dimension SF-36 is shown in Figure 1.

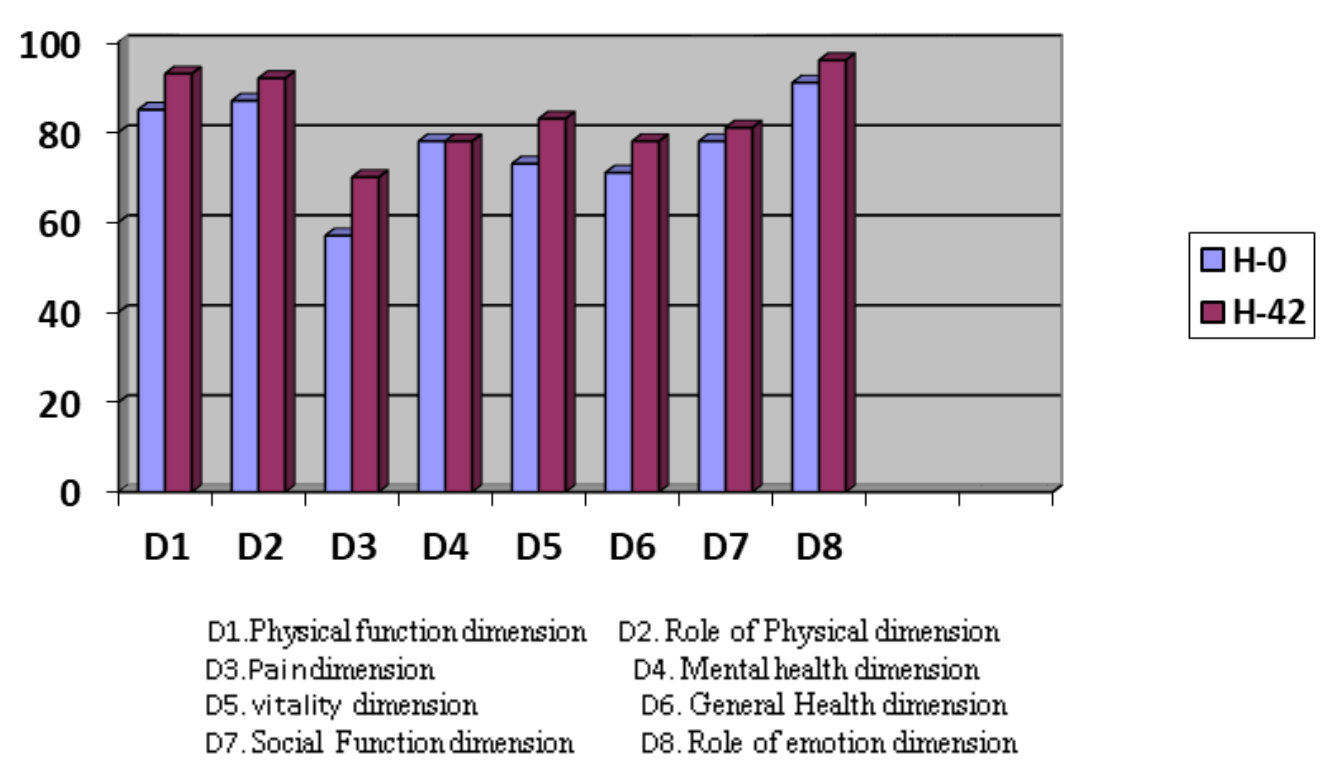

Figure 1. Graphic scores of each dimension SF-36, at Pre and Post Intervention.

\section{DISCUSSION}

The most hypercholesterolemia subjects are found in the age group 46-55 years. This is in accordance with the highest prevalence of hypercholesterolemia sufferers at the age of 4655 years and with the work of workers/ farmers/fishermen.
More hypercholesterolemia subjects in women were obtained. This is in accordance with the results of Basic Health Research on 2013 which stated that the prevalence of hypercholesterolemia in Indonesia is more in women, and hypercholesterolemia patients who visit the Herbal Medicine Research Center 
B2P2TO2T Tawangmangu also mostly are women (Ministry of Health, 2013).

SF- 36 is one of the instruments to assess quality of life, especially for sufferers of chronic diseases. SF-36 is a measure of quality of life related to health in the form of a questionnaire containing 36 questions and has been used frequently in Indonesia. Choice of answers between 2 to 6 possibilities. SF-36 has high sensitivity. Assessment results range from o to 100 . A score of 100 indicates the best quality of life and a value of $\mathrm{o}$ indicates the worst quality of life (Ware, 2005).

The results of the statistical test analysis found significant differences between SF-36 post-intervention scores compared to preintervention. There are 8 dimensions of assessment on the SF-36 questionnaire namely physical function (10 items), physical role (4 items), pain (2 items), general health (5 items), social function ( 2 items), vitality ( 4 items), the role of emotions (3 items) and mental health (5 items) (Lina, 2008).

The most frequent complaints of hypercholesterolemia sufferers are shoulder pain, neck pain, and body discomfort. The results of the analysis showed significant differences in physical function dimensions, pain dimensions, vitality dimensions, and general health dimensions. The hypercholesterolemia herbal formula has been shown to improve physical function, reduce pain, and improve vitality and general health.

Meanwhile, the results of the paired t-test analysis between pre-intervention and post-intervention did not differ significantly in the dimensions of physical roles, emotional roles, mental health, and social functions. The hypercholesterolemia herbal formula slightly increases the scores of these four dimensions.
The treatment of hypercholesterolemia herbal formula can significantly improve the level of quality of life. There were improvements in all eight dimensions of the SF-36 assessment, with significant improvements in the dimensions of physical function, pain, vitality and general health.

\section{REFERENCES}

Askandar T (2015). Ajar ilmu penyakit dalam, edisi-2. Uiversitas Airlangga. Surabaya.

Depkes RI (2007). Pedoman pengendalian penyakit jantung dan pembuluih darah. Depkes RI: Jakarta

Dyah I, Rhoito FS, Elizabeth MA, Latifah KD (2011). Zingiber cassumunar, Guazuma ulmifolia, and Murraya paniculata extracts as antiobesity: in vitro inhibitory effect on pancreatic lipase activity. Hayati Journal of Biosciences 18(1): 6-10. Retrieved from http://journal.ipb.ac.id/index.php/hayati

Gotay CC, Korn EL, McCabe MS, Moore TD, Cheson BD (1992). Quality of life assessment in cancer treatment protocols; research issues I Protocol Development J National Cancer Ins; 84: 5799.

Horrison (2001). Principles of internal medicine, $15^{\text {th }}$ edition. Mc Grow Hill, New York

Kemenkes RI (2013). Laporan riset kesehatan dasar tahun 2013.

Lina (2008). Hubungan antara parameter status nutrisi yang diukur dengan bioelectrical impedance analysis dan kualitas hidup yang dinilai dengan SF-36 pada pasien hemodialisis reguler; Tesis. Fakultas Kedokteran Universitas Sumatera Utara. Medan. 
Menteri Kesehatan (2010). Peraturan Menteri Kesehatan Republik Indonesia Nomor: o03/MENKES/PER/I/2010 tentang saintifikasi jamu dalam penelitian berbasis pelayanan kesehatan. Jakarta.

Testa MA, Simondson DC. (1996). Assesment of quality of life outcomes. N Eng $\mathrm{J}$ Med; 272: 619-26.

Ware J (2005). SF-36 health survey (ver. 1.0) for use in Australia. Australian Health Outcomes Collaboration (AHOC). University of Wallongong.

WHO (1997). WHOQOL measuring quality of life. Programme on mental health. Division of mental health and prevention of substance abuse. Word Health Organization. 